\title{
Miranda
}

Revue pluridisciplinaire du monde anglophone /

Multidisciplinary peer-reviewed journal on the English-

speaking world

$18 \mid 2019$

Guerre en poésie, poésie en guerre

\section{Bugging the Bog: Sonic Warfare, Earwitnessing and Eavesdropping in the Works of Seamus Heaney}

\section{Fanny Quément}

\section{OpenEdition}

Journals

\section{Electronic version}

URL: http://journals.openedition.org/miranda/16353

DOI: $10.4000 /$ miranda.16353

ISSN: 2108-6559

\section{Publisher}

Université Toulouse - Jean Jaurès

\section{Electronic reference}

Fanny Quément, "Bugging the Bog: Sonic Warfare, Earwitnessing and Eavesdropping in the Works of Seamus Heaney", Miranda [Online], 18 | 2019, Online since 15 April 2019, connection on 16 February 2021. URL: http://journals.openedition.org/miranda/16353; DOI: https://doi.org/10.4000/miranda. 16353

This text was automatically generated on 16 February 2021

\section{(c) $(1)$}

Miranda is licensed under a Creative Commons Attribution-NonCommercial-NoDerivatives 4.0 International License. 


\title{
Bugging the Bog: Sonic Warfare, Earwitnessing and Eavesdropping in the Works of Seamus Heaney
}

\author{
Fanny Quément
}

1 It was during World War II that Seamus Heaney's sense of hearing developed, with one ear straining to the baize of the Cossor wireless that broadcast news, music or stories to the noisy family kitchen in Mossbawn, County Derry (O'Driscoll 2008, 360), and the other following up sonic clues that signalled the presence of mice on the ceiling or horses behind a wall (Heaney 1996a, 4). Heaney's Nobel lecture, Crediting Poetry, tells how the child he was would listen to the adventures of spies and detectives like Dick Barton or Biggles (Heaney 1996a, 7-8) thanks to these radio waves which also transmitted "the frantic, piercing signaling of morse code" along with the broadcasters' voices emerging from the static, that "little pandemonium of burbles and squeaks" (Heaney 1996a, 6). For the child, listening to the radio was like spying on coded messages to be deciphered. The kitchen would therefore regularly turn into a listening post. Thanks to impalpable electromagnetic waves, the military was insidiously infiltrating that most domestic space the hearth is.

2 Nevertheless, it seems that the soundscape of the whole farmland was quite preserved from the war, even from its loudest blasts. As Guy Woodward explains,

[t]he Northern Irish countryside was physically altered by the construction of airfields and military bases, by the influx of evacuees and refugees, and by the blackout, but rural areas were not targeted in air attacks and suffered far less as a result. (Woodward 81)

No wonder, then, that Heaney remembers his birthplace as a kind of rural cocoon hardly impacted by the war. The beginning of the following paragraph is one of Heaney's most famous prose passages, but it is worth quoting it again:

I would begin with the Greek word, omphalos, meaning the navel, and hence the stone that marked the centre of the world, and reapeat it, omphalos, omphalos, omphalos, until its blunt and falling music becomes the music of somebody pumping water at the pumps outside our back door. It is Co. Derry in the early 1940 's. The 
American bombers groan towards the aerodrome at Toomebridge, the American troops manoeuvre in the fields along the road, but all of that great historical action does not disturb the rhythms of the yard. There the pump stands, a slender, iron idol, snouted, helmeted, dressed down with a sweeping handle, painted a dark green and set on a concrete plinth, marking the centre of another world. (Heaney 1980, 17)

The groans and manoeuvres of the American air and land forces are not even static, they cannot interfere with the rhythms of the rural world. They remain peripheral, barely noticed, as if the spellbinding dactyls of the pump ("omphalos, omphalos, omphalos") had a centrifugal power keeping them at a distance. That green, helmeted iron soldier watched the borders of Mossbawn, and Heaney trusted it, for even when news of bombings and casualty came up on the wireless, "none of [...] these wordspasms entered [him] as terror" (Heaney 1996a, 6). The farm and the family were intact or, as he rephrased it at the dawn of the $21^{\text {st }}$ century, "Wherever the world was, we were somewhere else" (Heaney 2006, 11).

5 The situation was different with the Troubles. In Glanmore, County Wicklow-where Heaney moved with his wife and children in 1972-news of the conflict was part of the soundscape of the cottage the Heaneys were renting. It was not simply heard from a distance, it was listened to as it mixed with the similarly recurrent sounds of nature: "I found myself [...] listening to the rain in the trees and to the news of bombings closer to home" (Heaney 1996a, 16). In this sentence, Heaney seems to grow aware of the fact that he is actively listening to the news. This constitutes a major change from his childhood experience. At the same time, the bombings feel "closer" to an adult's home that is no longer war-proof. A noise often associated with the Troubles and characteristic of the Northern Irish soundscape, namely, the helicopter drone, can be heard in "Triptych" ("And [I] listened to the thick rotations / of an army helicopter patrolling," Heaney 1979, 6), as well as in the ninth section of "Station Island" where it mangles the curlews' pastoral twittering: "only helicopters and curlews / Make their maimed music" (Heaney 1984, 84). As with the news, the British helicopters are listened to when the American planes were only vaguely heard in the distance during World War II. Their presence still haunts District and Circle, published eight years after the Good Friday Agreement, in which Heaney precisely recalls "the flash / Of one wild glance, like ghost surveillance / From behind a gleam of helicopter glass" (Heaney 2006, 42), a strangely silent image in which the absence of sound may be as terrifying as in Heaney's nightmarish description of the Troubles, "a bad dream with no sound" (Heaney 1975, 60).

6 The familiar sound of walkie-talkies also comes up in Heaney's lines, with "the sergeant with his on-off mike repeating / data about you, waiting for the squawk / of clearance" in "The Frontier of Writing" (Heaney 1987, 6), and this uncollected haiku:

Springtime in Ulster:

Aerials in hedges, squawk

Of walkie-talkies. (O'Driscoll 2008, 213)

7 In both cases, sound has to do with frontiers or liminal spaces, their control and their crossing. The very place of the onomatopoeia "squawk" (right before the enjambment in both quotes) makes room for the word to resound and can be associated with the idea of placing borders where there shouldn't be any since the sentences are unnaturally split. As the word "squawk" tears syntactical links apart, dispersing the morphemes, the "squawk / of clearance" controls the citizens" moves. Even if there was 
probably no allusion intended, the phrase might remind some readers of the "squawk box," a directional crowd-dispersal weapon based on ultrasonic frequencies whose existence and trial was reported by the New Scientist on 20 September 1973 but denied by the British army ("Army tests new riot weapon"). As for the haiku, it is no reverdie and the hedges it evokes are no longer the domesticated place where hedge-schools can form.

Whether the squawk box was really used or not, the rattling of helicopters and the bleeps and screeches of walkie-talkies broke into civilians' everyday lives and affected their minds, feeding the fears triggered by blasts and gunshots. Internalised, "tak[ing] up permanent residence in the body," they can be heard again any time a victim's memory is triggered and "play in post-traumatic stress disorder" (Obert 58). Such sounds were part of a sonic warfare, an insidious, protean and pervasive strategy relying on varied non-lethal sonic weapons ranging from the drums played in marches to the loud continuous sounds used as torture devices meant to make prisoners talk (Volcler 2011, 85). In this article, sonic warfare is to be understood as the use of sound as a weapon in the context of the Troubles, as in the examples given above. But it should also be more broadly conceived as a pervasive and elusive form of conflict similar to what Steve Goodman calls the "politics of frequency," a politics based sometimes on "affective mobilization" through sound (Goodman 34), sometimes on an "ecology of fear" (Goodman 97-98) or other control methods. Sonic warfare is therefore a particularly intrusive form of war that can disturb daily life even when no military war has been officially declared. With its "signatures on [its] own frequency" (Heaney $1984,94)$, Heaney's poetic voice shares in this warfare. He engages in the politics of frequency and his work becomes intrinsically linked with earwitnessing and eavesdropping.

Heaney's prose often merges the figure of the poet with that of the spy, recalling for instance how Marlowe "had tasted the thrills of espionage" before being denounced by informers (Heaney 1995, 18-19), or how the Mandelstams were spied on by Tolstoy (Heaney 1988, 71) when Osip's nickname, M., sounded much like a code name. He explains that the poetry of Zbigniew Herbert is more than dissident poetry in so far as it attempts to "discover whether that inner citadel of human being is a selfish bolt hole or an attentive listening post," an image that turns military eavesdropping into a poetic stance to be adopted at all times, in all circumstances. The association of the two figures-the poet and the spy-is not limited to Eastern European poets or to Heaney's prose. In "On his Work in the English Tongue," a poem dedicated to Ted Hughes, a bridge is turned into an "arch-ear to the ground, a listening post" (Heaney 2001, 61), and it seems that Heaney himself was intent on bugging the bog to draw inspiration from what he eavesdropped there: "I have always listened for poems, they come sometimes like bodies come out of a bog" (Heaney 1980, 34). The bog, like several other geographical spaces under study in this article, is a familiar place-yet it has its secrets.

Three aspects of sonic warfare will be addressed in order to examine its breaking-ins and Heaney's poetic answers to them: the way sound defines territories and intrudes on them, spying as a poetic activity and the poetic voice as a sonic weapon. 


\section{(Ear)Drums and territories}

11 Both the perception and the production of sound can be related to territorial behaviours. In line with to Roland Barthes's "Écoute" and Deleuze and Guattari's Mille Plateaux, François J. Bonnet's study of hearing is partly based on the idea that the ear is, first of all, the organ of fear, and that listening contributes to perceiving, constituting and defending a territory (Bonnet 42-58). An obvious Northern Irish example of the territorial dimension of sound is the use of drums by Orangemen marching to mark their territory, the loud drumming of the lambegs being a "soundmark," a community sound that characterises a soundscape (Schafer 274). In that case, both eardrums and drums are involved in the problematic charting of territories belonging to enemy communities. However, as familiar as this sound may seem, Paul Moore explains that the "numerous visual constructs that act as symbolic information about identity [in Ulster]" have been much studied whereas "the role of sound as symbolic signifier has not been so readily accepted" (Moore 266). Similarly, Heaney's imagery seems to have drawn more attention than his handling of the sonic dimension of the Troubles. Conor Cruise O'Brien is one of the few critics who emphasised the aural rather than the visual dimension of North in his 1975 review of the collection for The Listener. As important as the photographs from P. V. Glob's The Bog People may have been to Heaney, his interest in sound should not be downplayed.

The sound of drums is as recurrent in Heaney's works as the marching season in the Northern Irish calendar. As the following examples suggest, drumming functions sometimes as a signal or soundmark defining geopolitical territories, sometimes as a poetic device used to explore new territories. This analysis will rely on the terminology coined by R. Murray Schafer so as to identify clearly the various shapes drumming can take. Tracing the resonance of drums in Heaney's lines will show that he conceives the poet as an earwitness to the ways in which individuals relate to the sonic environments of their everyday lives.

The first of Heaney's “Ten Glosses" from Electric Light, entitled "The Marching Season," presents drumming as a repeatedly predictable signal communicating a clear, univocal message:

'What bloody man is that?' 'A drum, a drum!'

Prepossessed by what I know by heart,

I wait for Banquo and Macbeth to come

Unbowed, on cue, and scripted from the start. (Heaney 2001, 54)

The human being and the instrument are merged in the figure of the drum, a character entirely defined by his function as a messenger who becomes metonymically inseparable, even indistinguishable from his prop. Yet, paradoxically enough, this drum does not bring any piece of news. The Northern Irish marches are "scripted from the start" every year and Heaney knows the two plays-the universal Macbeth and the local drama-by heart. The signal broadcast during the marching season doesn't bring any piece of news, it manifests again and again a threatening presence. Drums address eardrums to make their presence felt and instil fear. However, the way this gloss alludes to Macbeth also endows drumming with a literary potential that is tapped, as we shall see, in other poems. communications tool, though not yet a poetic instrument. Along with other elements of 
the soundscape, it takes part in the identity-building processes Paul Moore focused on. This is how Heaney's persona addresses the ghost of William Carleton:

'I come from County Derry,

born in earshot of an Hibernian hall

where a band of Ribbonmen played hymns to Mary.

By then the brotherhood was a frail procession

staggering home drunk on Patrick's Day

in collarettes and sashes fringed with green.

Obedient strains like theirs tuned me first

and not that harp of unforgiving iron

the Fenians strung. A lot of what you wrote

I heard and did: this Lough Derg station,

flax-pullings, dances, summer crossroads chat

and the shaky local voice of education.

All that. And always, Orange drums.

And neighbours on the roads at night with guns.' (Heaney 1984, 66)

The common opposition of orange and green is at the same time reflected and complicated by the soundscape the lines compose: Marian hymns and Orange drums reinforce the territorial separation, but this contrast is nuanced and the text is less cliché than it may seem. Its ambiguities become striking when it is compared to the prose version of the same memory in "Mossbawn", written ten years earlier:

And the lift of the air is resonant, too, with vigorous musics. As summer evening carries the fervent melancholy strain of hymn-singing from a gospel hall among the fields, and the hawthorn blooms and the soft, white patens of the elderflower hang dolorous in the hedges. Or the rattle of Orange drums from Aughrim Hill sets the heart alert and watchful as a hare. (Heaney 1980, 20)

In the prose version, hymns are associated with a Christian imagery and a bucolic landscape untainted yet by drunken singers. The territory is clearly polarised as Mossbawn is superimposed on the site where the Battle of Aughrim was fought: the choir is associated with a place of melancholy and suffering-the Latin roots of the adjective "dolorous" ring with a Catholic timbre-under the threat of the approaching drums. The soundscape reconstituted in "Station Island" differs from this version: it creates a paradoxical mirror-effect between the two apparently opposed communities.

The dances (possibly involving crossings) and the small talk at crossroads are meeting points proving the two sides were not always clearly separate. Interviewed by O'Driscoll, Heaney remembered that as a child he would sometimes "[go] out to the end of the lane at Mossbawn to watch an Orange band march and to wave at people [his family] knew" (O'Driscoll 2008, 134). But the poem's diction and sounds reveal a darker mirroring. The phrase "in earshot" implies the existence of a territory defined and covered or guarded by hearing, in which the child's identity takes root, but there may be more to it than that. The literal meaning of the ending "shot" is re-activated by the "guns" mentioned a few lines below: the Marian hymns are suddenly and unexpectedly associated with weaponry and violence. The child's ear was impacted, informed, scarred and maybe even traumatised by all these sounds. Believing that the owners of the guns are necessarily Unionists would be a hasty deduction: "guns" doesn't quite rhyme with "drums" but partly echoes "education" and the Fenians" "iron" harp, 
whose strings resemble prison bars and whose tunes were supposed not to be part of this soundscape. This pattern recalls Unionists don't have a monopoly on weapons. The "neighbours" could be from either side and the rhyming of "Derry" with "Mary" eventually sounds as ironically clichéd as the clumsy association of "guns" with "drums." The poem blurs borders and superimposes territories, showing at the same time that the definition of a community's territory through sound is a common phenomenon.

Moreover, the nominal sentence "And always, Orange drums" turns an intermittent, seasonal sound into a "keynote" (Schafer 272) constantly resounding, with a strong iambic rhythm recalling that political and cultural domination went hand in hand. A latent, drone-like drumming is in fact constantly lurking in Heaney's soundscapes, but it is not always that of a lambeg. "The Catholic population also have their marching bands," Moore stresses, adding that they are nevertheless associated with "softer, quieter tones" such as the bodhrán's (270). Even if associating the bodhrán with republicanism and the lambeg with unionism is a historical aberration (Moore 271; Obert 47), it is one of the symbols around which identities and mindsets are built. Technically speaking, a lambeg is undeniably louder than a bodhrán, and is therefore hardly musically compatible with it, but the two have not always been culturally incompatible.

Reading Heaney's work can help reconsider the simplistic opposition between the two kinds of drums. Heaney does employ ironic litotes to evoke the deafening and sickening sound of the lambegs in "Whatever You Say, Say Nothing"-"Last night you didn't need a stethoscope / To hear the eructation of Orange drums" (Heaney 1975, 58)-but he also pictures "the big drum being hefted" by a Hib (O'Driscoll 134) and relies on figures of speech to amplify the sound of some other drums which, being tuned to Republican hymns, could exercise an influence. Thus, he suggests through diction and imagery what Ciaran Carson makes clear in the structure of The Twelfth of Never (1998) by juxtaposing "Twelfth Day" and "The Ay O'Haitch," dealing respectively with Protestant and Catholic marches as equal sources of "partisan noise pollution" (Obert 47).

For instance, the metaphor of "the whole country tun[ing] / to the muffled drumming / of ten thousand engines" in "Funeral Rites" (Heaney 1975, 17) sounds ominous: this drumming is a keynote sound pregnant with more sectarian violence, and the fact that it is "muffled" makes it all the more powerful. This drumming is echoed by the "purring" of a hearse at another funeral, that of a fisherman killed by a bomb planted in a pub:

I missed his funeral,

Those quiet walkers

And sideways talkers

Shoaling out of his lane

To the respectable

Purring of the hearse (Heaney 1979, 17)

The casual, offhand assertion "I missed his funeral" suggests it might have been a slip on the part of the poet who wants to "[s]tay clear of all processions" (Heaney 1984, 63). "Shoaling" turns the mourners into animals driven by a gregarious instinct while the metric parallelism of the lines "Those quiet walkers / And sideways talkers" evokes a cadence as regular as that of a marching drummer, something very different from the "rhythm" the poet discovers on his own on a boat by the end of the poem. In addition to the irony of the adjective "respectable", one can hear a pun in "hearse," the 
homophone of herse: the regular sound of the purring seems to work as a defensive gate deafening everyone as it falls. The verb "hear" is graphically present but muted, its central phoneme being buried deep down in the word "hearse." Gathering behind their own sound barrier, the mourners can no longer hear anything.

The sound of drums therefore works as a signal, a keynote or a soundmark used by both communities to define territories, build identities and make their presence felt even if it is only ghostly. As such, it pervades everyday life and is likely to constitute a traumatic sound. However, it can also be freed from its geographical and historical context, thus turning out to be a poetic matter or matrix. A drumming different from that of the Orangemen and Hibs can be heard in Station Island:

Morning stir in the hostel. A pot

hooked on forged links. Soot flakes. Plumping water.

The open door letting in the sunlight.

Hearthsmoke rambling and a thud of earthenware

drumming me back until I saw the mug

beyond my reach on its high shelf, the one

patterned with cornflowers, blue sprig after sprig

repeating round it, as quiet as a milestone,

old and glazed and haircracked. (Heaney 1984, 87)

This indoor scene in still-life style is animated by sound effects that stimulate the speaker's auditory imagination. Indeed, the structure and dynamics of this strongly visual poem rely on rhythm. With their series of nominal sentences, the first lines follow the movement of a progressive awakening. Their many full stops seem to separate rhythmical units without them showing any metric consistency. With the phrase "plumping water," the meaning of which is matched by its plosives, one may think that some energy is being progressively released, especially since the sentences then lengthen with a momentum that keeps defying metrics. Even the smoke rings seem to be making noise since they are rambling and the imperative "hear the smoke" might be encrypted in the noun "hearthsmoke." The enjambment from one stanza to another draws the readers' attention to the verb "drumming," interestingly used transitively with a human being (the speaker) as a direct complement. This drumming is not an object of perception, it is a subject taking control of the speaker's memory, drawing him back to the primitive times of his childhood or even further back in history, for the milestone can be reminiscent of Delphi's omphalos which, as mentioned before, was dear to Heaney. As the water is plumping he is pumping again. This is a perfect example of "anamnesis," an "effect of reminiscence in which a past situation or atmosphere is brought back to the listener's consciousness, provoked by a particular signal or sonic context" (Augoyard and Torgue, 21).

The pleasant reminiscence of a peaceful domestic space which is at the origin and the core of this poem is therefore triggered by a percussive, iterative sound like that produced by drums-or by fingertips marking beats, like Heaney's on his steering wheel when driving made him coin new lines (O'Driscoll 446). The pattern printed on the mug offers a visual equivalent of a rhythm which is, this time, regular, with the repetition of the monosyllabic word "sprig" imitating the motif of the frieze. The milestone is not mute but "quiet" and the breaks signalled by the full stops are not silences but pauses thanks to which words can resound. This "drumming," far from bringing back traumatic memories, leads the way to a new sonic realm. 
Heaney's work therefore testifies to the power of drumming, be it creative or destructive. Even though the impacts left by sounds are not as easily detectable as those left by bullets, Heaney shows "what a sonic body can do" (Goodman 16) to the land as a "giant body whose language reveals symptoms of real historical contusions" (Hart 66), or to real bodies and minds. This is when the figure of the witness merges with that of the doctor. In "No Man's Land the speaker introduces himself as a deserter who would be as helpless as a doctor facing a corpse if he came back to the battlefield:

I deserted, shut out

their wounds' fierce awning,

those palms like streaming webs.

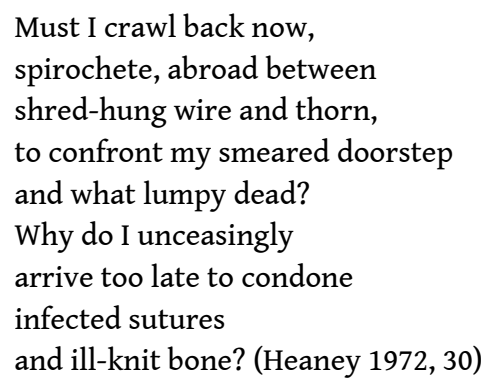

"Shut[ting] out" these wounds, the poet seems to refuse to speak for the "dumb mouths" they are, to borrow an image from Julius Caesar (Shakespeare 1623a, 249). But he cannot accept silence either and is therefore facing a dead end. Comparing himself to a bacterium ("spirochete"), he fears he might make the infection worse. He cannot cure but can observe and record, and the precision with which the bog bodies are described in Wintering Out and North are reminiscent of a coroner's report. However, the Grauballe Man is not seen as a corpse: "Who will say 'corpse' / to his vivid cast?" (Heaney 1975, 36); and it is a living body that is auscultated in "Orange Drums, Tyrone, 1966", for "The air is pounding like a stethoscope" (Heaney 1975, 68).

As eardrums are hit by sound-waves, so bodies and minds are marked by sound events presented again in the form of written words thanks to Heaney's "echoic memory" (Bonnet 29). The readers are not exposed to the sounds themselves, but to their traces as recorded by the attentive author. When the poet-as-earwitness' listening becomes more acute and active, he resembles a doctor sounding bodies and hoping that not all hearts will beat in step with sectarian drums. But the figure of the doctor is combined with another one for whom acute hearing matters as much: that of the spy always eavesdropping on his surroundings, as familiar as they may be.

\section{The poet and the spy}

If the poet's first task is to listen, there is, however, an essential difference between the poet's and the spy's practices as conceived by Bonnet. According to him, the spy's ear is trained to decipher, check or read information, thus losing its primary function (hearing all present or emerging sound events) and regrettably focusing on sounds that make sense like morphemes in speech (Bonnet 140). Looking for clues in a highly directional and selective way, the spy's ears turn out to be deaf to the surroundings they should on the contrary embrace joyfully (Bonnet 147). Heaney's conception of listening is much closer to this enthusiastic embracing than to the oriented eavesdropping Bonnet associates with spying, yet it remains metaphorically linked to 
the figure of the spy as analysed, this time, by Peter Szendy in his study of "the aesthetics of espionage."

Wintering Out immediately invites the readers to be all ears so as to eavesdrop or "overhear" in the sense Szendy gives to this verb, taking the prefix "over" as a kind of superlative: to listen in the most intense way (Szendy 26). "Fodder," the first poem in this collection, is indeed about "eaves" projecting from a haystack and "falling" as they weather (Heaney 1972,3). The description takes on an auditory dimension: as "eaves" is a poetic word for "eyes," it seems that the eyelids of some sleepy eyes are closing, and the linguistic components of the verb "eavesdrop" seem to be disseminated, encrypted in the participle "falling" and its subject "eaves." The next poem, "Bog Oak," can help decode this invitation to eavesdrop as the word is this time used in its full form:

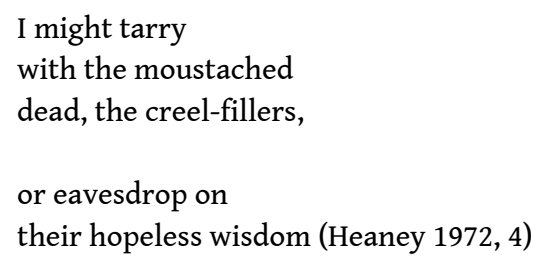

31 Eavesdropping and listening carefully remain central in Heaney's later collections, even in poems that deal with marital or filial love. Field Work offers another occurrence of the word "eaves" with the line "Let me listen under your eaves" (Heaney 1979, 46) in a love poem to Marie, Heaney's wife. The sonnet sequence "Clearances," written after the death of Heaney's mother, starts with the following imperative: "Teach me now to listen, / To strike it rich behind the linear black" (Heaney 1987, 26). It seems that there exists a lode of sound the poet may learn how to tap so that his lines, printed in black ink, will address the ear as much as the eye.

While the omnipresence of surveillance devices is blatant in Carson's works, cameras and bugs remain discretely concealed but nonetheless crucial in Heaney's. Technology and its opaque terminology pervades Carson's Belfast Confetti (1989, "Pye Pockerfones" 35, 78, "a Telescope Starlight II Night Observation Device (NOD) - Noddy, for short, [...] the stoolie-pigeon spool" 38, "IR filter" 78, "surveillance radar" 92), where the structure of the panopticon turns out to be central (79). In his novel Exchange Place, it seems any character can be "a spy, at least in a manner of speaking" $(2012,92)$. The "parasitic transmitters, Trojan Horse transistors, synaptic grafts or buds" that may be "planted everywhere: in phones and door-handles and light fitments" $(2012,164)$ create an atmosphere of dissimulation and dissemblance where people are "talking of this when they mean that, doing that instead of this" $(2012,165)$. Heaney's references to such devices are far less frequent, but North records once and for all the fact that places like hotels were bugged during the Troubles: "zoom lenses, recorders and coiled leads / Litter the hotels" (Heaney 1975, 57).

Even though direct references to the technology of surveillance remain occasional, Heaney developed a poetic interest in listening devices. For him, there exists a lode of sound he may learn how to tap so that his lines, printed in black ink, will address the ear as much as the eye. Carefully crafting each poem, the poet sometimes seems to end up wiretapping his own lines as an answer to the stifling atmosphere of constant surveillance. In "Mycenae Lookout," a poem indirectly dealing with the Troubles as Heaney rewrites Aeschylus's Oresteia, the watchman is paradoxically a "blind spot" condemned to silence as "the ox would lurch against the gong [his tongue] / And deaden it" (Heaney 1996b, 29). The reality of this war is then revealed through sound, 
not sight: the watchman can hear Clytemnestra's "love-shout" resounding in the entire palace like a battle cry, but the watchman himself is spied on and has to watch his tongue since the palace's roof is "like an eardrum" (Heaney 1996b, 35). If the poet wants to gain sway, his post is therefore not so much the sentinel's look-out as that giant eardrum dominating the scene. He has to perch on a listening post as Sweeney does on his beech, rising above the ivy's "tapers" (Heaney 1984, 100), a word signalling that even the deepest forests can be bugged. As he taps the sap of this beech, the poet seems to wiretap nature so as to record its tapping rhythms in his lines. Bugging the bog, playing on words like "tapers" or building listening posts in his lines, Heaney appropriates the surveillance technologies he disapproves of so as to turn them into poetic weapons.

And he would wiretap all lines, not only his own. As a teacher, he intended to turn his students' ears into "bugging devices," a metaphor originating from his reading of Solzhenitzyn:

In his novel The First Circle, Solzhenitzyn sets the action in a prison camp on the outskirts of Moscow where the inmates are all highly skilled technicians forced to labour at projects dreamed up by Stalin. The most important of these is an attempt to devise a mechanism to bug a phone, but what is to be special about this particular bugging device is that it will not simply record the voice and the message but that it will identify the essential sound patterns of the speaker's voice; it will discover, in the words of the narrative, 'what it is that makes every human voice unique', so that no matter how the speaker disguises his accent or changes his language, the fundamental structure of his voice will be caught. The idea was that a voice is like a fingerprint, possessing a constant and unique signature that can, like a fingerprint, be recorded and employed for identification.

Now one of the purposes of a literary education as I experienced it was to turn the student's ear into a poetic bugging device, so that a piece of verse denuded of name and date could be identified by its diction, tropes and cadences. And this secret policing of English verse was also based on the idea of a style as a signature. (Heaney 1980, 43)

This excerpt shows how crucial it is to make the difference between, on the one hand, the totalitarian listening denounced by Solzhenitzyn, a Stalinist dream in which people would be as deaf as Bonnet's spies, and on the other, the poetic listening Heaney practices and trains his students for. Heaney's approach to literature is not simply about close reading, it is about close listening, even if Charles Bernstein hadn't coined the phrase yet. Learning how to identify a voice is a first step in a process of control and appropriation remedying the situation described in "The Ministry of Fear": "Ulster was British but with no rights on / The English lyric" (Heaney 1975, 65). Countering the policy imposed by the Ministry of Fear, the poet-as-teacher and his students take control of metropolitan voices to make them fructify on their own ground, according to the double meaning of the participle "policing" (to regulate and to cultivate). Politics are meddling with aesthetics again. This time, the sonic battlefield is not the farm but the classroom and the poems themselves. Heaney's daily task as a teaching poet reflected concerns that were both circumstantial and universal.

Still according to Heaney's conception of teaching as explained through the bugging metaphor, listening is an active practice shared by writers and readers alike, a posture different from the one he sketches when describing Dorothy and William Wordsworth listening to the river-like sound of the air in the wood near Dove Cottage: "The couple listen, they surrender, the noise of water and the voice of the air minister to them" 
(Heaney 1980, 68). Heaney's auditory experiences can be intense but they don't imply a similar abandon. On the contrary, Heaney stages listeners carefully lending their ears to their surrounding, with a tension that makes complete surrender impossible. See for instance how the following speaker from Station Island, someone guiding a child around a farm, insists on the fact that his ear is experienced, trained: "I heard much that you could not hear" (Heaney 1984, 36). One could also think of Heaney's recurrent use of the word "strain": in the excerpt from Mossbawn quoted above, the hymns that draw the listener's attention form a "fervent melancholy strain" (Heaney 1980, 20) towards which the ear strains in its turn, as does that of the poet portrayed in Crediting Poetry, "straining to hear the totally persuasive voice behind all the other informing voices," "straining towards a strain" (Heaney 1996a, 51). Heaney associates the tension of such strains with poetic maturity in an essay on Yeats stating that "the mature music is not a lulling but an alerting strain" (Heaney 1980, 72). From this perspective, sounds are bait to the ear but listeners remain active, tense, as their desire to listen is never fully satisfied.

Listening actively is part of Heaney's "poetics of responsibility" (Ní Ríordáin). It is important to "take the strain," as Heaney says in the last line of "A Kite for Michael and Christopher (Heaney 1984, 44), handing over the string that directs the "tightened drumhead" of a kite flying over the land like one more eardrum surveying the place. As the last poem in North already suggested, the poet cares as much for the ear as for the people, for the two are linked:

I sit weighing and weighing

My responsible tristia.

For what? For the ear? For the people? (Heaney 1975, 73)

As he shoulders the responsibility to listen, the poet develops his own art of counterintelligence (Quément 41-42). "I'm no Cold War hero," said Heaney when asked if he had smuggled in or out any books or manuscripts when travelling between the eastern and western blocks. But he did portray himself as a secret agent at the service of poetry.

Contrary to what poems like "England's Difficulty" or "Exposure" seem to suggest (Bennett 104; Vendler 87), the figure of the double agent might not be entirely negative. "[F]orked-tongue on the border-bit" (Heaney 1975, 58), "whispering morse (Heaney 1975, 60), Heaney could be considered as a traitor by any side: while some Irishmen and women must have felt the resentment clearly expressed by the nationalist Heaney meets on a train-“"When, for fuck's sake, are you going to write / Something for us?"' (Heaney 1996b, 25)-other readers thought that Heaney's North was advocating for sectarian violence (Carson 1975) or feeding people with a simplistic ideology (Lloyd 13-40). The ambiguity of his position has been pointed out (Longley 140-69), but it might be a fruitful ambiguity rather than a deplorable one.

In fact, “England's Difficulty" (Heaney 1998, 85) might not be so much about Ireland's opportunity as about the poet's responsibility. As the poem explains, the little Heaney's everyday life during the Second World War mostly consisted in "mov[ing] like a double agent among the big concepts." While nationalists hoping for the defeat of the UK praised Lord Haw Haw for his propaganda ("He's an artist, this Haw Haw"), Heaney's family sided with "the enemies of Ulster." Heaney then recalls becoming "[a]n adept at banter," "cross[ing] the lines with carefully enunciated passwords" and "report[ing] back to nobody," thus elaborating a debatable but efficient defensive strategy. If the 
double agent can be seen as a figure of the poet it is because, in Heaney's fictions, he is "neither internee nor informer" (Heaney 1975, 73), a "dual citizen" (Heaney 1987, 15) with a "middle voice" whose "cunning" (Heaney 1975, 32) is to be differentiated from duplicity. As awful as wars may be, it seems there are strategies the poet can learn from them, listening from a distance. Alert and all ears, this ambassador from the "Republic of Conscience" (Heaney 1987, 15) served his fellow citizens without being at the service of any of the three parties involved in the conflict (republicans, unionists, and the British army). This is how his poetic voice became engaged in the peacebuilding process on the one hand, tapping into the "unifying power" of sound (Obert 10), especially music, and in a relentless daily sonic warfare on the other, a conflict of another kind that is partly independent from specifically Northern Irish issues.

\section{Engaging in sonic warfare}

41 Books may not make any sound but the poetic voice is a sonic weapon for Heaney. In "Whatever You Say Say Nothing," he seems to take off a gag, refusing the silence imposed by the Northern Irish saying. Indeed, the normative voice of the community anonymously spreading the title's imperative is answered by the poet's individual statement "Yet I live here, I live here too, I sing" (Heaney 1975, 57), a statement echoed in the following section "Of the 'wee six' I sing" (Heaney 1975, 59), where the simple present sounds very much like that of a speech act. Written in response to a journalist in search of "views / On the Irish thing" (Heaney 1975, 57)-a typical euphemism-this poem opposes Heaney's own voice and sound memories to the ubiquitous clichés in the media. A simple observation such as the one he makes in "Triptych," "Our island is full of comfortless noises" (Heaney 1979, 5) constitutes, indirectly, a defense of poetry in times of war, when "Song and Suffering" (Heaney 1988, xii), as Heaney allegorically represented them, seem hardly compatible. Indeed, the allusion to the scene from The Tempest in which Caliban says to Stephano and Trinculo "Be not afeard, the isle is full of noises" (Shakespeare 1623b, 87) suggests that other sounds might win over the "comfortless noises." As Heaney writes in his essay "On Poetry and Professing": "'Sounds and sweet airs, that give delight, and hurt not': that, as a description of the good of poetry and of literature in general, will do" (Heaney 2002, 69-70). It is a moral principle that is phrased here: the root of poetic good is therefore in the listening and in the resounding. The silence imposed by the sirens that interrupted Heaney and David Hammond when they were on their way to record a few poems and songs (Heaney 1988, xii) was necessary, but temporary.

Moreover, it seems that Heaney's intense listening and sonic resistance are not limited to the context of armed conflicts. For him both are part of an everyday life marked by conflicts or tensions. One can notice, for instance, that he draws attention to "the wrap-around vulgarity and vacuity of the muzak and media we're all made to suffer" (O’Driscoll 2008, 469) and mentions the Muzak company again when comparing Oscar Wilde's “Ballad of Reading Gaol” to Wilfred Owen's war poetry (Heaney 1995, 94). Heaney experienced the spreading of Muzak's background soundtracks around shops and diners and all sorts of venues since the company became successful as early as the 1950s. However, he may not have known that it was founded by a Major General, George Owen Squier, teaming with Harold Burris-Meyer, a master of theatrical scenery who, during World War II, had also helped the army with operations requiring sound 
effects (Volcler 2017). The Muzak backgrounds we are all "made to suffer" are only one instance of the increasingly common intermingling of the military with the civil, especially through entertainment (Volcler 2017, Goodman), and of a pervasive sonic warfare going on in public and private spaces. As Muzak and its equivalents aimed at taking control of ears and minds, Heaney could only shoulder the responsibility to engage in the "politics of frequency" by broadcasting poetry, which he did literally, regularly and directly into people's homes thanks to radio waves. Nevertheless, the radio is not Heaney's only sonic weapon.

Comparing the power of lyricism to "the note of the soprano which cracks glass" (Heaney 1988, xx), Heaney metaphorically ranges poetry amongst the weapons based on high frequencies and ultrasounds like the "squawk-box" mentioned earlier. Surprisingly enough, the poet does have something in common with the engineers working on real sonic weapons to be used on frontlines, in cases of civil unrest, or simply on streets like the "mosquito" devices (originally conceived to get rid of rats) that were meant to drive young people away from places where they were considered as pests. This common point is an interest in what Steve Goodman calls the "unsound," frequencies that cannot be heard because they are either too low or too high, but which are still sound-waves, sonic bodies likely to impact anyone exposed to them. "Sonic warfare is [...] as much about the logistics of imperception (unsound) as it is perception," Steve Goodman writes (Goodman 31), and Heaney shares in this logic. While the word unsound "aptly describes the colonization of inaudible frequencies by control," it "also names that which is not yet audible within the normal bandwidth of hearing-new rhythms, resonances, textures, and syntheses" (Goodman 228-229), that is to say some poets' materials, as when Heaney speaks of T.S. Eliot's "bat-frequency" (Heaney 2002, 29).

Bats find their way (and food) thanks to ultrasonic echo-sounding, a technique Heaney associates with another of his predecessors, James Joyce: "echo-sounding" (Heaney $1984,94)$ is part of the advice he receives from the ghost of Joyce he meets in Station Island. In the same collection, "A Bat on the Road" begins with a quote from A Portrait of the Artist as a Young Man: "A batlike soul waking to consciousness of itself in darkness and secrecy and loneliness" (Heaney 1984, 40; Joyce 144). Readers are invited to be all ears so as not to miss the "slight / bat-thump and flutter" coming with the following lines. This bat is not only the prostitute from Joyce's novel. It is also a figure of the blind author:

flying blind over ashpits and netting wire; invited by the brush of a word like peignoir,

rustles and glimpses, shot silk, the stealth of floods

So close to me I could hear her breathing (Heaney 1984, 40)

These lines defy religious puritanism at the same time as they celebrate the subtle erotics of language (Allison 31): it is not the peignoir itself but its soft foreign sounds that tease the speaker, or an imperceptible breathing. Heaney's italics signal the phrase comes again from A Portrait: these words about breathing were literally inspired by Joyce as they echoed in Heaney's memory.

It seems, in fact, that there exists a whole broadcasting network of Irish poets relying on echo-location as a way to find one's geographical and stylistic bearings. In her "Letter to Friends," Leontia Flynn compares "the cacophony / of texts and tweets and emails" to "bat-squeaks in a cave / to steer us in the dark" (39), antiphonically relating 
to them to find her own mode of echo-sounding. One of Paul Muldoon's most famous poems is his "Sonogram" (342), inspired by the use of ultrasound in medical imaging. John Kilfeather, the narrator in Carson's novel Exchange Place, also undergoes an echocardiogram, "familiarly referred to as an ECHO among the medical profession" (96) and remembers a friend of his who had "one of those big old Echo, or was it EKO valve radios" (133) which worked best in the dark.

With Eliot and Joyce as examples, Heaney makes room for the unsound and its subversive potential. Frequencies at risk of remaining unheard are an alternative bandwidth towards which the poet's ear is straining, to the point that they seem to constitute a kind of alternative soundscape. Defining poetry as an "undersong" (Heaney 1991, 59) or "undermusic" (Heaney 1995, 29, 85, 135), Heaney draws attention to the powerful under or counter current it constitutes. Moreover, contrary to what the words "song" and "music" might seem to imply, these poetic frequencies on the threshold of hearing are not necessarily melodious. Sometimes they evoke the bass of a drone, like the "dynamo-hum" Heaney perceives in Marlowe's Tamburlaine (Heaney 1995, 29) or the "turning, humming resonance" he enjoys in Dylan Thomas's lines (Heaney 1995, 133). One may also think of "Wheels within Wheels" and the hum of the bike wheel Heaney loved to turn as a child: "the space between the hub and rim / hummed with transparency" (Heaney 1991, 46). In this synaesthetic experience, the humming is to the ear what transparency is to sight-something that is hardly hearable yet perceptible-and it is what makes both the memory and the lines powerful. It is also a droning sound, the antiphon to the drone of helicopters, like the poetic drumming resisting the drums of sectarianism.

A lengthy study of the poem "Canopy," from Heaney's last collection The Human Chain, will finally show how Heaney's poetry may help readers regain control of their sonic environments and everyday lives in a state of constant sonic warfare. "Canopy" was written in memory of an installation set up by Winston David Ward in the yard of Harvard University: small speakers wrapped in fabric were hung in trees that were "turning a young green" (Heaney 2010, 44) when Heaney saw them. His description of the installation evokes subtle sounds on the threshold of silence:

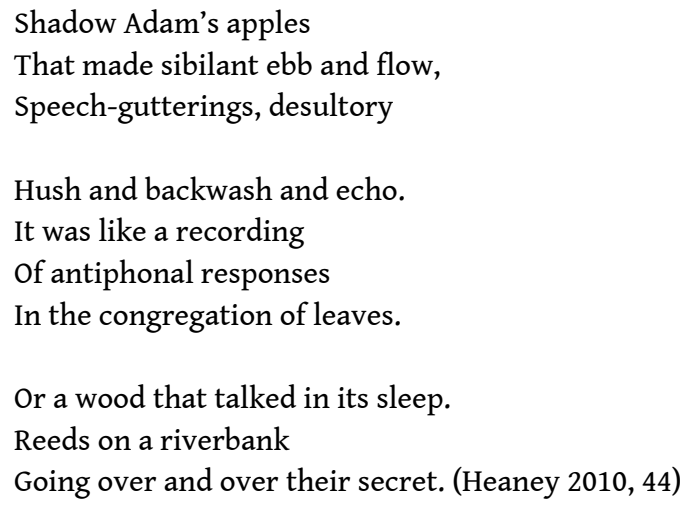

Hanging in the trees, the speakers are like talking fruit revealing what Roland Barthes called the "rustle" (bruissement) of language, for the sounds they broadcast are not so much those of nature as phonemes to be picked and relished.

"Canopy" shows the power of "echo" not simply because the word rhymes with "flow," but because echoes multiply within the poem, to such an extent that Heaney's personal memory of this installation can be appropriated in many different ways: the lines quoted above can trigger childhood memories of the reeds whispering Midas's secret, 
or more scholarly reminiscences of antiphonal literary forms, and the poem is itself an answer to the scene from the Divine Comedy known as the wood of the suicides. Dante is directly referred to: "Dante's whispering wood- / The wood of the suicides- / Had been magicked to lover's lane" (Heaney 2010, 45), but the text might also be alluding to Beckett. Indeed, the speakers are said to be like "bat-fruit in the gloaming": if the image brings in again the significance of ultrasounds, the word "gloaming" might work as a double allusion, to the popular love song "Roamin' in the Gloamin" on the one hand, and Beckett's draft for "Rough for Theatre I" entitled "The Gloaming" on the other. The latter is a fragment in which a character as blind as a bat expresses his nostalgia for twilight, the time of day when "Canopy" is set, and asks "[h]ow the trees are doing." Heaney seems to answer that they are not doing so bad after all and to elaborate on the blind man's last cue: "I can stay for hours listening to all the sounds" (Beckett 45).

51 In "Canopy," Heaney manages to give an idea of what Ward's installation sounded like at the same time as he mixes this memory with other sonic traces left by his readings and revived on the occasion of his visit or when writing the poem. It should be noted that the poem offers a positive experience of what Schafer called "schizophonia," "the split between an original sound and its electroacoustic reproduction" (Schafer 273). Although Heaney is a lover of nature and its soundscapes, he doesn't reject this canopy of sounds as the copy of a paradise lost, for schizophonia achieves something here-the affective mobilisation of an audience through sound:

People were cocking their ears,

Gathering, quietening,

Stepping on to the grass,

Stopping and holding hands. (Heaney 2010, 44)

As people "cock" their ears they are, in a way, arming themselves, standing ready to backfire. While most sonic weapons, especially the ones aiming at crowd dispersal, rely on centrifugal force, the power of this sound installation lies in the centripetal force it exerts on people who suddenly become aware of their surroundings and stop in the middle of their activities or thoughts to hold hands in this Human Chain, celebrating humane feelings as well as, maybe, humanities, since the scene takes place in Harvard Yard. Like Ward's installation, Heaney's lines contribute to a "tactical deployment whose objective is that of intensification, to the heightening of collective sensation, an attractive, almost magnetic, or vortical force, a force that sucks bodies in toward its source" (Goodman 34), firstly because they keep a trace of Ward's ephemeral in situ artwork based on the most labile and fleeting material that sound is, and secondly because they might in their turn make people stop and cock their ears. As disconnected from political issues as it may seem, Heaney's lyricism can nevertheless be considered as an engagement in a ubiquitous and ongoing sonic warfare.

While World War II hardly had any impact on Mossbawn and the family life there, the Troubles left many sonic traces in Heaney's mind and lines. But there is something even worse than the sounds of bombs and sirens and constant surveillance: the obliteration of hearing, as in the silent nightmare Heaney imagines wars to be like ("a bad dream with no sound" Heaney 1975, 60). Whether in the context of an armed conflict like the Troubles, or in that of the more latent and yet deeply impacting sonic warfare going on in post-modern societies, Heaney praises listening as an essential principle. His entire work can be read as training for the ear. It testifies to the poet's 
attention to his surroundings (sonic or other) and expects a similar attention from the reader-listener. Under the influence of the detective and secret agent stories he listened to as a child, and later on in the context of the Troubles, Heaney grew conscious of the power of sound and the necessity to stay alert and listen even in times of peace. His poetic relation to military surveillance and sonic warfare may be defined as one of appropriation and subversion. If the bugging devices he developed were only metaphorical, he did appropriate for real another military tool that had quickly become part of the everyday life of civilians-the radio-by becoming a broadcaster literally involved in the politics of frequency at a time when the BBC was much dominated by English voices. Amongst the sound experts referred to throughout this article, Juliette Volcler, Steve Goodman and François J. Bonnet share the same concern: how can we re-appropriate our sonic environments to avoid being controlled through sounds and the ideologies they convey? Although it is nowhere near the experimental works Volcler has in mind, Heaney's poetry constitutes one of the "passionate sonic gesture[s]" ("geste sonore passionné" Volcler 2011, 6) she calls for, or an aesthetic resistance that, quite unexpectedly, shares features with the afro-futurism studied by Goodman. Heaney explores what is imperceptible, unheard or unsound. In doing so, he walks on the same ground as that explored by the engineers working on sonic weapons, at the same time as he follows one of Bonnet's paths out of the discursive and ideological uses of sound. While real sound-waves can trigger physical and psychological reactions that are hard to control, from a mere finger-drumming to deep anxiety, their re-production in poetry does not subject the readers to the same predetermined cause-effect relationships. On the contrary, Heaney's verbal handling of soundscapes is likely to complicate and challenge these relations, revealing the mutability and the semantic richness of sounds that may have seemed univocal. Printed words belong in the realm of the unsound but can become sonic bodies and re-sound if readers train and strain their ears.

\section{BIBLIOGRAPHY}

Allison, Jonathan. “The Erotics of Heaney's Joyce” Colby Quarterly 30 (March 1994): 25-32.

“Army tests new riot weapon.” New Scientist 59:864 (20 September 1973): 684.

Augoyard, Jean-François and Henri Torgue (eds.). Sonic Experience: A Guide to Everyday Sounds. Montreal : McGill-Queen's University Press, 2006.

Barthes, Roland. Le bruissement de la langue : Essais critiques 4. Paris : Éditions du Seuil, 1984.

---. “Écoute.” In L'Obvie et l'obtus : essais critiques 3. Paris : Éditions du Seuil, 1982.

Beckett, Samuel. The Collected Shorter Plays. New York: Grove Press 1984.

Bernstein, Charles. Close Listening: Poetry and the Performed Word. New York: Oxford University Press, 1998. 
Bennett, Charles. “The Use of Memory: On Heaney's Stations." In Politics and the Rhetoric of Poetry: Perspectives on Modern Anglo-Irish Poetry. Eds. Jane Mallison and Tjebbe A. Westendorp. Amsterdam : Rodopi, 1995. 95-106.

Bonnet, François J. Les Mots et les sons : un archipel sonore. Paris : Éditions de l'éclat, 2012.

Carson, Ciaran. "Escaped from the Massacre?” The Honest Ulsterman 50 (Winter 1975): 183-86.

---. The Twelfth of Never. Old Castle: Gallery Press, 1998.

---. Exchange Place. Belfast: Blackstaff Press, 2012.

Flynn, Leontia. Profit and Loss. London: Jonathan Cape, 2011.

Goodman, Steve. Sonic Warfare: Sound, Affect, and the Ecology of Fear. Cambridge, Massachusetts: The MIT Press, 2010 (epub).

Glob, Peter Vilhelm. The Bog People: Iron-Age Man Preserved. London: Faber and Faber, 1969.

Hart, Henry. Seamus Heaney: Poet of Contrary Progressions. Syracuse, New York: Syracuse University Press, 1992.

Heaney, Seamus. Crediting Poetry: The Nobel Lecture. New York: Farrar, Straus and Giroux, 1996a.

---. District and Circle. London: Faber and Faber, 2006.

---. Electric Light. London: Faber and Faber, 2001.

---. Field Work. London: Faber and Faber, 1979.

---. Finders Keepers: Selected Prose 1971-2001. 2002. London: Faber and Faber, 2003.

---. The Government of the Tongue: the 1986 T. S. EliotMemorial Lectures and Other Critical Writings. 1988. London: Faber and Faber, 1989.

---. The Haw Lantern. London: Faber and Faber, 1987.

---. The Human Chain. London: Faber and Faber, 2010.

---. North. London: Faber and Faber, 1975.

---. Opened Ground. London: Faber and Faber, 1998.

---. Preoccupations: Selected Prose 1968-1978. 1980. London: Faber and Faber, 1984.

---. The Redress of Poetry. New York: Farrar, Straus and Giroux, 1995.

---. The Spirit Level. London: Faber and Faber, 1996b.

---. Seeing Things. London: Faber and Faber, 1991.

---. Station Island. London: Faber and Faber, 1984.

---. Wintering Out. London: Faber and Faber, 1972.

Joyce, James. A Portrait of the Artist as a Young Man. 1916. London: Penguin Classics, 2003.

Lloyd, David. Anomalous States: Irish Writing and the Post-Colonial Element. Durham: Duke University Press, 1993.

Longley, Edna. Poetry in the Wars. Newcastle upon Tyne: Bloodaxe Books, 1986.

Moore, Paul. "Sectarian Sound and Cultural Identity in Northern Ireland." In The Auditory Culture Reader. Eds. Les Back and Michael Bull. Oxford: Berg, 2003. 265-79.

Muldoon, Paul. Poems: 1968-1998. London: Faber and Faber, 2001. 
Ní Ríordáin, Clíona. "Pour une poétique de la responsabilité : l'œuvre poétique de Seamus Heaney." Université Lyon 2, 2002. PhD thesis.

Obert, Julia C. Postcolonial Overtures: The Politics of Sound in Contemporary Northern Irish Poetry. Syracuse: Syracuse University Press, 2015.

O’Driscoll, Dennis. Stepping Stones: Interviews with Seamus Heaney. London: Faber and Faber, 2008.

Quément, Fanny. “'At my buried ear': Seamus Heaney’s Pastoral Sounding.” Green Letters 20:1

(2015): 34-46.

Schafer, R. Murray. The Soundscape: Our Sonic Environment and the Tuning of the World. New York: Knopf, 1977.

Shakespeare, William. Julius Caesar. 1623. London: The Arden Shakespeare, 1998.

---. The Tempest. 1623b. New Haven: Yale University Press, 2006.

Szendy, Peter. Sur écoute : une esthétique de l'espionnage. Paris : Éditions de Minuit, 2006.

Vendler, Helen. Seamus Heaney. London: HarperCollins, 1998.

Volcler, Juliette. Contrôle : comment s'inventa l'art de la manipulation sonore. Paris : La Découverte, 2017.

---. Le Son comme arme : les usages policiers et militaires du son. Paris: La Découverte, 2011.

Woodward, Guy. Culture, Northern Ireland and the Second World War. Oxford: Oxford University Press, 2015.

\section{ABSTRACTS}

Although the violence of the Troubles is sometimes directly shown in Seamus Heaney's poetry, it is far more often indirectly suggested by sounds breaking into the domestic space or natural environment. In the poetic soundscapes his words compose, helicopter throbs and all sorts of drumming constitute a continuous background drone punctuated by many a blast. As it collects the various testimonies of a poet who was also an earwitness, this oeuvre keeps a trace of sonic attacks even if they do not leave impacts on walls or scars on bodies. This article will examine how Heaney's poetic voice appropriates military bugging devices and engages in a sonic warfare, retaliating against intrusive sound-waves that haunt minds as much as homes.

Si la violence des Troubles est parfois directement montrée dans la poésie de Seamus Heaney, elle est bien plus souvent indirectement suggérée par des intrusions sonores dans l'espace domestique ou l'environnement naturel. Dans le paysage sonore poétique que le poète élabore, le roulement des tambours et le vol des hélicoptères constituent un bourdon constant que ponctuent de nombreuses détonations. En tant qu'elle recueille divers témoignages auditifs, cette œuvre garde la trace d'attaques sonores bien que celles-ci ne laissent pas d'impact sur les murs ni de cicatrices sur les corps. Cet article propose de voir comment la voix poétique de Heaney détourne les dispositifs d'écoute militaires pour s'engager dans une guerre sonore, répondant aux ondes intrusives qui hantent les esprits comme autant de maisons. 
INDEX

Mots-clés: Seamus Heaney, études du son, environnement sonore, Seconde Guerre mondiale, Troubles, espionnage

Keywords: Seamus Heaney, sound studies, sonic environment, World War II, Troubles, espionage

\section{AUTHORS}

FANNY QUÉMENT

Docteure de l'université Sorbonne Nouvelle, EA 4398 PRISME

fanny.quement@gmail.com 